\title{
Operasi Optimal Sistem Tenaga Listrik Mempertimbangkan Kestabilan Transien Menggunakan Oppositional Krill Herd Algrithm
}

\author{
Gilang Hari Pratomo, Adi Soeprijanto, dan Ni Ketut Aryani \\ Departemen Teknik Elektro, Fakultas Teknologi Industri, Institut Teknologi Sepuluh Nopember (ITS) \\ E-mail: adisupits@gmail.com, ketut.aryani@gmail.com
}

\begin{abstract}
Abstrak-Penelitian ini menunjukan studi tentang optimasi sistem tenaga listrik mempertimbangkan kestabilan transien. Pertambahan kebutuhan tenaga listrik yang tidak sebanding dengan pertambahan infrastruktur tenaga listrik menyebabkan sistem sistem beroperasi lebih dekat pada batas kestabilan. Pada sistem dengan biaya pembangkitan yang paling murah karena sudah meggunakan analisa aliran daya optimal, belum tentu ketika dilakukan pengujian kontingensi sistem tetap stabil. Studi ini menggabungkan analisa aliran daya optimal dan pengujian kestabilan transien. Pengujian menggunakan metode simulasi berbasis waktu dan pusat inersia. Generator dimuodelkan secara multimesin dan dilihat kurva ayunan sudut rotornya. Stabil atau tidaknya sistem dianalisa dari sudut rotor terhadap pusat beban. Metode yang digunakan adalah Oppositional Krill Herd Algorithm. Keluaran dari penelitian ini adalah biaya pembangkitan yang termurah dan secara preventif mencegah ketidakstabilan transien pada saat kontingensi tertentu.
\end{abstract}

Kata kunci-Transient Stabilty Constrained Optimal Power Flow, Optimal Power Flow, Tme Domain Simulation, Center of Inertia, Oppositional Krill Herd Algorithm.

\section{PENDAHULUAN}

$\mathrm{K}^{\mathrm{s}}$ EBUTUHAN tenaga listrik di seluruh negara diprediksikan mengalami peningkatan sebesar $67 \%$ selama periode 2011 sampai 2035 dengan pangsa terbesar dari sektor industri sebesar $41 \%$. Untuk memenuhi kebutuhan tenaga listrik yang meningkat maka diperlukan infrastruktur pembangkit listrik yang memadahi dan mengacu pada prinsip ekonomi. Dalam arti yang lain, selain pembangkit harus memenuhi daya yang dibutuhkan konsumen, pembangkit juga berkewajiban meminimalkan total biaya pembangkitan. Ketika sistem tenaga interkoneksi mengambil peranan untuk meningkatkan keandalan sistem tenaga listrik maka fasilitas pendukung sistem tenaga listrik dituntut beroperasi dalam kondisi optimal. Stabilitas sistem tenaga listrik baru dikenali pada tahun 1920 dan didefinisikan sebagai sifat dari sistem tenaga listrik yang akan tetap berada di kondisi setimbang setelah mengalami gangguan [1]. Salah satu contoh permasalahan kestabilan adalah kejadian kehilangan sinkronisasi generator yang terjadi pada tanggal 12 Mei 2014 yang menyebabkan pemadaman. Gangguan besar seperti putusnya saluran transmisi maupun lepasnya pembangkit dan beban yang besar dapat menimbulkan gangguan stabilitas khususnya gangguan stabilitas transien.

Transient Stability Constraint Optimal Power Flow (TSCOPF) adalah sebuah metode untuk mencari daya optimum pada setiap unit pembangkit dengan mempertimbangkan kestabilan transien. Optimal Power Flow
$(O P F)$ adalah metode mencari nilai pembangkitan yang optimum dengan biaya pembangkitan yang ekonomis dan juga memperhatikan besarnya kapasitas dan jaringan mana yang dipakai untuk menyalurkan daya. Analisa aliran daya yang optimal dengan mempertimbangkan stabilitas transien adalah metode preventif yang digunakan untuk mengamankan sistem tenaga listrik sebelum terjadi gangguan. Dengan penjadwalan setiap unit pembangkit yang tepat maka biaya operasi pembangkitan dapat ditekan dan secara umum meningkatkan tingkat keandalan dan tingkat keamanan sistem. Diharapkan dengan metode ini ketika sebuah sistem tenga listrik diberikan kontingensi tertentu maka pembangkit tidak hanya stabil namun juga beroperasi dengan biaya seminimal mungkin.

Pada penelitian ini, dibahas permasalahan OPF dengan batasan kestabilan transien dengan melakukan uji kontingensi pada bus tertentu. Metode analisa transien yang dilakukan untuk mengetahui apakah suatu pembangkit stabil atau tidak adalah dengan menggunakan Time Domain Simulation (TDS). Sedangkan pengotimalan tiap unit pembangkit dengan mempertimbangkan generator stabil atau tidak menggunakan metode Oppositional Krill Herd Algortithm (OKHA). Metode optimasi OKHA merupakan pengembangan metode Krill Herd Algorithm (KHA) yang dikembangkan oleh Gandomi dan Alavi. KHA adalah metode optimasi yang terinspirasi dari kejadian ilmiah berupa pergerakan krill untuk mencari makan. Untuk meningkatkan konvergensi dan hasil simulasi, dikembangkan metode oppositional based learning (OBL) yang diimplementasikan pada KHA.

\section{FORMULASI ANALISA ALIRAN DAYA OPTIMAL MEMPERTIMBANGKAN KESTABILAN TRANSIEN}

\section{A. Formulasi Aliran Daya Optimal}

Permasalahan OPF adalah masalah optimasi dimana persamaan matematisnya dapat kita tulis sebagai berikut :

Meminimalkan fungsi dari

$$
\begin{array}{ll} 
& f(x, u) \\
\text { Dari: } & g(x, u)=0 \\
& h(x, u) \leq 0
\end{array}
$$

Pada kasus ini, fungsi objektif $f(x, u)$ diambil sebagai biaya pembangkitan total, batasan persamaan diambil dari persamaan aliran daya, dan batasan pertidaksamaan $\mathrm{h}(\mathrm{x}, \mathrm{u})$ diambil dari batas saluran dan keamanan.

Vektor $\mathrm{x}$ dan $\mathrm{u}$, parameter dari fungsi ini, disebut state variable vector dan control variable vector. State variable vector dapat ditulis sebagai berikut: 


$$
x^{t}=\left[P_{\text {slack }}, V_{L}, Q_{g}\right] \text {, }
$$

Dimana, yang termasuk dalam state variable $x$ adalah daya aktif bus slack, tegangan bus beban $V_{L}$, dan daya reaktif generator $Q_{g}$. Pada kasus ini control variable vector u dapat didefinisikan sebagai berikut:

$$
u^{t}=\left[P_{g}, V_{g}, T_{v}, Q_{e}\right]
$$

Dimana control variable vector $\mathrm{u}$ terdiri dari daya pembangkitan aktif kecuali bus slack $\mathrm{P}_{\mathrm{g}}$, magnitude tegangan terminal generator $\mathrm{V}_{\mathrm{g}}$,ratio tap transformer $\mathrm{T}$, dan daya pembangkitan reaktif atau penyerapan daya reaktif dalam bentuk peralatan kompensasi, seperti kapasitor maupun bank reaktor $\mathrm{Q}_{\mathrm{c}}$.

\section{B. Fungsi Objektif}

Fungsi objektif dinyatakan sebagai jumlah biaya pembangkitan dari seluruh pembangkit dari sistem dengan kurva biaya pembangkitan didekati dengan fungsi kuadratik dari keluaran daya aktif generator.

$$
f(u)=C_{T}=\sum_{x=1}^{N_{C}}\left(a x P_{g x}^{2}+b x P_{g x}+c x\right)
$$

Dimana CT adalah total biaya pembangkitan. Sedangkan a, $\mathrm{b}$, dan $\mathrm{c}$ adalah koefisien biaya pembangkitan generator. $\mathrm{P}_{\mathrm{gx}}$ adalah besar pembangkitan daya aktif dari generator $\mathrm{x}$ dan $\mathrm{N}_{\mathrm{g}}$ adalah jumlah bus generator.

\section{Batasan Persamaan}

Persamaan pada OPF didefiniskan sebagai batasan persamaan:

$$
\begin{gathered}
P_{G_{x}}-P_{D_{x}}-\sum_{y=1}^{N_{B}} V_{x} V_{y}\left(G_{x y} \cos \delta_{x y}+B_{x y} \sin \delta_{x y}\right)=0 \\
Q_{G_{x}}-Q_{D_{x}}-\sum_{y=1}^{N_{B}} V_{x} V_{y}\left(G_{x y} \cos \delta_{x y}-B_{x y} \sin \delta_{x y}\right)=0
\end{gathered}
$$

Dimana $\mathrm{V}_{\mathrm{x}}, \mathrm{V}_{\mathrm{y}}$ adalah tegangan pada bus $\mathrm{x}$ dan bus $\mathrm{y}, \mathrm{P}_{\mathrm{Gx}}$ dan $\mathrm{Q}_{\mathrm{Gx}}$ adalah daya aktif dan daya reaktif, masing - masing pada generator $\mathrm{x}, \mathrm{P}_{\mathrm{Dx}}$ dan $\mathrm{Q}_{\mathrm{Dx}}$ adalah beban aktif dan reaktif pada bus x. $\mathrm{G}_{\mathrm{xy}}, \mathrm{B}_{\mathrm{xy}}, \delta_{\mathrm{xy}}$, masing - masing adalah konduktansi, suseptansi, dan perbedaan tegangan fasa antara bus $\mathrm{x}$ dan bus y. $\mathrm{N}_{\mathrm{B}}$ adalah jumlah bus.

\section{Batasan Pertidaksamaan}

Tegangan generator, keluaran daya aktif dan daya reaktif dari bus $\mathrm{x}$, harus berada pada batas atas dan batas bawahnya masing - masing. Untuk generator constraint dapat dirumuskan sebagai berikut:

$$
\begin{gathered}
V_{G x}^{\min } \leq V_{G x} \leq V_{G x}^{\max } \\
P_{G x}^{\min } \leq P_{G x} \leq P_{G x}^{\max } \\
Q_{G x}^{\min } \leq Q_{G x} \leq Q_{G x}^{\max }
\end{gathered}
$$

Dimana $V_{G x}^{\min }, V_{G x}^{\max }$, adalah tegangan generator minimum dan maksimum masing - masing dari bus x. $P_{G X}^{\min }, P_{G x}^{\max }$ adalah daya aktif minimum dan maksimum dari bus x. $Q_{G x}^{\min }$, $Q_{G x}^{\max }$ adalah daya reaktif minimum dan maksimum dari bus $\mathrm{x}$. Pengaturan tap transformer dibatasi oleh batas atas dan batas bawah transformer, tergantung dari spesifikasi transformator.

$$
T_{x}^{\min } \leq T_{x} \leq T_{x}^{\max }
$$

Dimana $T_{x}^{\min }, T_{x}^{\max }$ adalah masing - masing minimum dan maksimum pengaturan batas tap dari transformer $\mathrm{x}$.

Pengaturan batas keamanan seperti pembebanan saluran transmisi dan tegangan pada bus beban dapat dinyatakan sebagai berikut:

$$
\begin{gathered}
V_{L x}^{\min } \leq V_{L x} \leq V_{L x}^{\max } \\
S_{L x} \leq S_{L x}^{\max }
\end{gathered}
$$

Dimana $V_{L x}^{\min }, V_{L x}^{\max }$ adalah tegangan pada bus beban maximum dan minimum pada bus x. $S_{L x}, S_{L x}^{\max }$ adalah aliran daya komplek dan aliran daya maksimum saluran transmisi.

\section{E. Pengujian Kestabilan Transien}

Ketidakstabilan diterjemahkan sebagai bentuk simpangan yang tidak tetap pada sudut rotor akibat kurangnya torsi untuk menyeimbangkan. Periode analisa transien biasanya $3-5$ detik tergantung dari gangguan [2]. Simpangan ini dapat dilihat dari hasil analisa simulasi berbasis waktu berupa kurva ayunan dari mesin - mesin. Dari hasil tersebut dapat didefinsikan apakah suatu sistem stabil atau tidak. Kurva ayunan adalah hasil plot dari sudut rotor ataupun kecepatan rotor terhadap waktu. Jika kurva dari mesin diplotkan kepada sumbu yang sama maka dapat diamati kestabilan dari sebuah sistem. Apabila bentuk kurva ayunan tersebut menyebar maka dapat dikatakan tidak stabil, namun apabila menetap pada nilai tunak yang baru maka bisa dikatakan stabil [3] . Osilasi sudut rotor generator menunjukan sistem stabil walaupun tidak teredam. Hal ini disebabkan permodelan generator berupa generator klasik dan tidak dimodelkannya peredaman sistem.

Persamaan ayunan memperlihatkan arah dari simulasi berbasis waktu, yang dari hasil persamaan tersebut didapat respon dinamik dari state variabel $\left(\delta_{\mathrm{i}}\right.$ dan $\left.\omega_{\mathrm{i}}\right)$. Hasil turunan berupa sudut rotor dapat digunakan untuk menentukan Center Of Inertia (COI) dari sudut - sudut rotor [4] dan dapat mempresentasikan kestabilan dari sistem. Sudut yang setara dengan pusat inersia suatu daerah dapat dinyatakan sebagai berikut:

$$
\begin{aligned}
\delta_{\text {CoI } j} & =\frac{1}{M_{j}} \sum_{i=1}^{N_{g}} M_{\mathrm{i}} \delta_{\mathrm{i}} \\
M_{j} & =\sum_{i=1}^{N} M_{\mathrm{i}}
\end{aligned}
$$

Dimana $\delta_{\text {corl } j}$ dan $M_{j}$ adalah sudut rotor yang setara inersia mesin suatu daerah dan jumlah inersia total dari area $\mathrm{j}$, dimana $M_{\mathrm{i}}$ dan $\delta_{\mathrm{i}}$ dapat dinotasikan sebagai momen inersia dan sudut rotor dari mesin $\mathrm{i}$ daerah $\mathrm{j}$. Kriteria sederhana untuk menentukan dari kestabilan transien dinyatakan dari penyimpangan sudut rotor terhadap COI, dan oleh karena itu batasan pertidaksamaan dari kestabilan transien dinyatakan sebagai:

$$
\left|\delta_{i}-\delta_{\cos }\right|_{\max } \leq \delta_{\max }
$$

Dimana $\left|\delta_{i}-\delta_{\cos }\right|_{\max }$ mewakilkan deviasi maksimum dari generator ke i terhadap COI dan $\delta_{\max }$ adalah sudut rotor maksimum yang diijinkan. Sehingga untuk menentukan kestabilan suatu sistem, jika salah satu sudut rotor suatu generator menyimpang dari COI setelah gangguan dihilangkan lebih besar dari $180^{\circ}$ maka kestabilan transien suatu sistem bisa dikatakan tidak stabil. Namun jika sudut rotor dari semua mesin masih dalam keadaan seimbang dan masih dalam batas toleransi maka dapat dikatakan suatu sistem stabil.

\section{F. Perhitungan Nilai Fitness}

Untuk nilai masing - masing individu pada OKHA, perhitungan aliran daya dilakukan dan nilai fitness dihitung dari masing - masing individu.

Kemudian nilai fitness ditambah dengan penyimpangan variabel kontrol terhadap biaya pembangkitan sebagai hasil analisa aliran daya. Sebagai hasilnya nilai fitness dari masing - masing individu krill dinyatakan sebagai berikut: 


$$
\begin{aligned}
& f(x, u)=f_{i}+K_{V} \sum_{i=1}^{N_{P Q}}\left(V_{i}-V_{i}^{\mathrm{lim}}\right)^{2}+K_{Q} \sum_{i=1}^{N_{G}}\left(Q_{g i}-Q_{g i}^{\lim }\right)^{2} \text { C. Perhitungan Pergerakan Individu Krill } \\
& +K_{p}\left(P_{\text {siack }}-P_{\text {slack }}\right)^{z}+K_{T}
\end{aligned}
$$

Dengan $V_{i}^{\lim }, Q_{g i}^{\lim }, P_{\text {sim }}^{\lim }, K_{T}$ didefinisikan sebagai:

$$
\begin{aligned}
& V_{i}^{\lim }=\left\{\begin{array}{l}
V_{\mathrm{i}}^{\max }{ }_{0} V_{\mathrm{i}}>V_{\mathrm{i}}^{\max } \\
V_{\mathrm{i}}^{\min }{ }_{\mathrm{s}} V_{\mathrm{i}}<V_{\mathrm{i}}^{\min }
\end{array}\right\} \\
& Q_{i}^{l i m}=\left\{\begin{array}{l}
Q_{g i}^{\max }{ }_{0} Q_{g i}>Q_{g i}^{\max } \\
Q_{g i}^{\min }{ }_{,} Q_{g i}<Q_{g i}^{\min }
\end{array}\right\} \\
& P_{\text {siack }}=\left\{\begin{array}{l}
P_{\text {siack }}^{\max }, P_{\text {slack }}>P_{\text {slack }}^{\max } \\
P_{\text {siack }}, P_{\text {slack }}<P_{\text {slack }}^{\min }
\end{array}\right\} \\
& K_{T}=\left\{\begin{array}{c}
10^{10_{x}}\left|\delta_{\mathrm{i}}-\delta_{\operatorname{coI}}\right|_{\max }>\delta_{\max } \\
0_{i}\left|\delta_{\mathrm{i}}-\delta_{\operatorname{coI}}\right|_{\max }<\delta_{\max }
\end{array}\right\}
\end{aligned}
$$

Dimana $f(x, u)$ adalah nilai fitness dari individu ke $\mathrm{x}$, dan iterasi ke u. $N_{P Q}$ menunjukan jumlah bus beban. $V_{i}^{\lim }, Q_{g i}^{\lim }$ dan, Plim mek menyatakan batas atas atau batas bawah dari variabel terkait. $K_{V}, K_{Q}, K_{P}$, dan $K_{T}$ adalah beban pinalti dari daya keluaran slack bus, keluaran daya dari daya reaktif bus generator, magnitud tegangan, dan batas kestabilan transien.

\section{PENERAPAN TSCOPF DENGAN OKHA}

Krill Herd Algorithm (OKHA) adalah sebuah metode optimasi yang dikembangkan dari KHA yaitu sebuah optimasi baru meta-heuristik kecerdasan berkelompok berdasarkan untuk memecahkan masalah optimasi. Pengembangan OKHA ini terletak pada modifikasi individu dengan mencari individu oposisi yang dinamakan Opposed Based Learning (OBL) dan Opposition based generation jumping. Hal ini didasarkan pada perilaku menggiring kawanan krill dalam menanggapi proses biologis dan lingkungan. Telah pertama kali diperkenalkan oleh Gandomi dan Alavi pada tahun 2012. Dalam optimasi ini algoritma, fungsi tujuan untuk gerakan krill merupakan koombinasi posisi makanan dan kepadatan kawanan tertinggi. KHA mengulangi pelaksanaan tiga gerakan dan mengikuti arah pencarian yang meningkatkan nilai fungsi tujuan. Tiga gerakan ini adalah:
1. Movement induced
2. Foraging activity,
3. Random diffusion.

\section{A. Inisiasi Awal}

Yaitu berupa inisiasi populasi dan inisiasi variabel mula. Setiap individu krill memilki beberapa variabel yang menentukan fitness dari individu krill tersebut. Variabel tersebut berupa pembangkitan aktif generator, tegangan generator pada bus, seting tap trafo, dan daya inject reaktif. Besar variabel ini masih diantara batas yang ditentukan pada (9) dan (12).

\section{B. Penentuan Opposite Population berdasar OBL}

Dari setiap variabel yang ada disetiap individu krill maka dapat dibentuk matrix nilai maksimal dan nilai minimal yaitu matrix $U_{M}$ dan $V_{m}$. Hasil pembangkitan matrix nilai variabel berdasarkan proses acak namun masih berada dalam batas maksimum $U_{m}$ dan batas minimum $V_{m}$ dapat dinotasikan dengan nama $P_{\mathrm{m}}$. Dari nilai tersebut maka dapat dinyatakan opposite population $\left(P_{\mathrm{m}}^{*}\right)$ :

$$
P_{m}^{*}=U_{m}+V_{m}-P_{m}
$$
sebuah dimensi ke $-\mathrm{n}$, yang dinyatakan dengan:

$$
\frac{d w_{D}}{d t}=W_{p}^{\text {new }}+W_{F_{D}}^{\text {new }}+W_{D_{D}}^{\text {new }}
$$

Dimana $W_{p}^{\text {new }}$ adalah pergerakan yang diinduksi oleh individu krill yang lain, $W_{F_{p}}^{\text {new }}$ adalah foraging motion dan $W_{\mathbb{D}_{b}}^{\text {new }}$ adalah physical difussion dari individu krill.

\section{Pemutakhiran Posisi}

Pada proses ini, individu krill akan mengubah posisi semula ke posisi yang lebih baik berdasarkan induction motion, foraging motion, dan random diffusion motion. Berdasarkan tiga pergerakan di atas, pemutakhiran individu krill ke $\mathrm{k}$ dapat dinyatakan sebagai:

$$
\begin{aligned}
u_{p}^{\text {new }}= & u_{p}^{\text {new }}+\left(W_{p}^{\text {new }}+W_{F_{p}}^{\text {new }}+W_{D_{p}}^{\text {new }}\right) \\
& \times P_{c} \sum_{q=1}^{n_{d}}\left(U_{q}-L_{q}\right)
\end{aligned}
$$

Dimana $n_{d}$ adalah jumlah variabel, $U_{q}$ dan $L_{q}$ adalah batas atas dan batas bawah dari variabel ke q. $P_{c}$ adalah konstanta posisi dengan nilai diantara [0,2]. Untuk mempercepat performansi atas proses optimasi dan mempercepat konvergensi maka proses crossover dan mutation dimasukan dalam proses OKHA.

\section{E. Opposition Based Generation Jumping}

Setelah pemutakhiran posisi, dilakukan pembangkitan populasi oposisi sama seperti proses di awal. Jika proses ini dilakukan pada populasi setelah dimutakhirkan maka proses evolusi ini akan dipaksa melompat ke kandidat solusi yang baru yang lebih baik dibanding populasi mula. Berdasarkan jumping rate $\left(\mathrm{J}_{\mathrm{R}}\right)$, setelah proses induksi, foraging, dan random diffusion, populasi yang baru dibangkitkan dan populasi oposisi dihitung. Dari perbandingan ini, individu yang memiliki fitness yang paling baik itu yang dipilih. Pada setiap pembangkitan, ruang pencarian dipersempit untuk menghitung titik oposisi dimana dinyatakan sebagai berikut:

$$
O P_{m_{n}}=\operatorname{Min}_{n}^{p}+\operatorname{Max}_{n}^{p}-P_{m n} \quad \text { (26) }
$$

Dimana $\left[\operatorname{Min}_{n}^{\mathrm{p}}, \operatorname{Max}_{n}^{\mathrm{p}}\right]$ adalah matrix interval dari parameter parameter yang ada dari setiap individu krill yang sudah mengalami pemutakhiran posisi. Dengan interval yang lebih kecil dari $\left[u_{n}, v_{n}\right]$ maka diharapkan individu yang terbangkit memiki fitness yang lebih baik. 


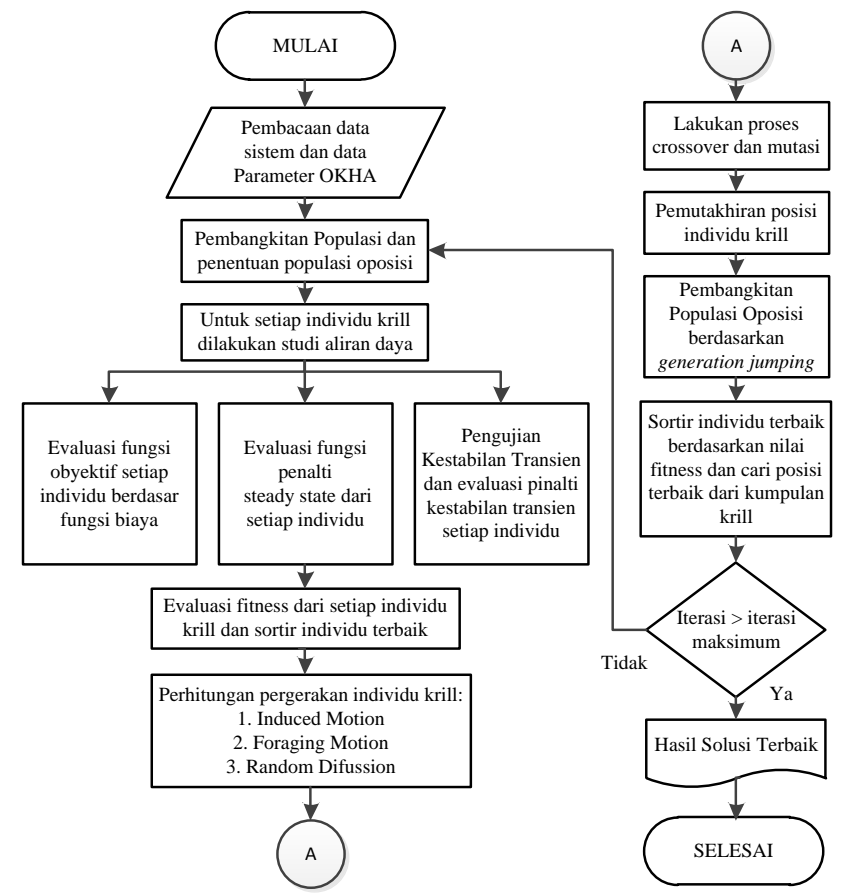

Gambar 1. Diagram alir penerapan TSCOPF dengan OKHA.

\section{Simulasi}

\section{A. Sistem IEEE 30 bus}

Sistem uji coba pertama menggunakan IEEE 30 bus dengan diagram satu garis, sedangkan data bus dan data saluran berasal dari referensi. Parameter generator berupa konstanta inersia dan reaktansi transien diambil dari referensi. Batas bawah dan batas atas tegangan diatur pada 0.95 p.u. dan 1.05 p.u. Kasus kontingensi yang digunakan pada pengujian ini menggunakan gangguan tiga fasa di saluran $2-5$ dekat dengan bus 2. Sehingga besar hubung singkat diasumsikan sama antara hubung singkat di saluran dekat bus 2 dan di bus dua. Waktu pemutusan saluran diambil pada waktu 0.5 detik setelah gangguan. Waktu total simulasi adalah 5 detik dengan step time sebesar 10ms.

Pada tabel 1 tampak hasil simulasi OPF dan TSCOPF, dimana tidak ada generator yang melebihi batas pembangkitannya maupun melanggar batas minimal dan maksimal tegangan bus. Pembeda dari hasil simulasi dengan beberapa metode tersebut adalah biaya pembangkitan.

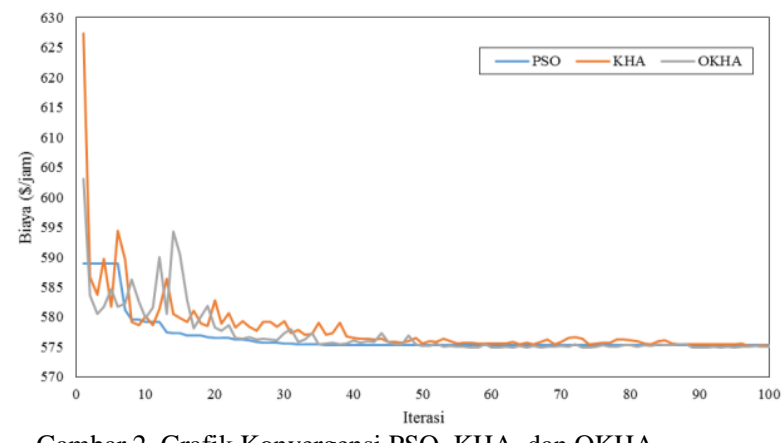

Gambar 2. Grafik Konvergensi PSO, KHA, dan OKHA

Untuk kasus OPF dasar, biaya pembangkitan termurah dihasilkan menggunakan metode OKHA yaitu sebesar $\$ 574.43$ / hari. Hasil simulasi OPF divalidasi oleh metode matematis quadratic programming (QP) yang nilai pembangkitannya tidak jauh dari nilai tersebut yaitu $\$ 576.89$ / hari. Sedangkan pada TSCOPF urutan metode dengan biaya termahal ke termurah adalah GA, EPNN, ABC, PSO, KHA, dan OKHA. Hasil pembangkitan termurah TSCOPF pada IEEE 30 bus menggunakan OKHA dengan biaya sebesar $\$ 574.743 /$ hari. Sedangkan biaya pembangkitan termahal TSCOPF adalah $\$ 585.62$ / hari. Namun walaupun menggunakan metode OKHA untuk kasus TSCOPF masih lebih mahal \$0.31 dibanding metode OKHA untuk kasus OPF. Namun biaya pembangkitan TSCOPF yang termurah masih lebih mahal \$0.31 dibanding harga pembangkitan OPF yang termurah. Harga pembangkitan TSCOPF lebih mahal disebabkan nilai ekonomis dari sistem operasi yang dikorbankan untuk meningkatkan performa kestabilan sistem.

Pada gambar 2 menunjukan konvergensi dari metode PSO, KHA, dan OKHA. Metode OKHA memiliki konvergensi yang cukup bagus dibandingkan KHA dan PSO. Pada metode OKHA memang terdapat lonjakan pada iterasi awal sampai iterasi ke 20, namun dapat teredam setelah iterasi ke 20. Semakin banyak individu yang dibangkitkan maka konvergensi yang dihasilkan semakin baik. Hal tersebut ditunjukan dengan individu berjumlah 80 dan 100 sudah konvergen pada iterasi ke 10. Sedangkan untuk individu yang berjumlah 20 memang rata - rata konvergensi terhadap iterasi cukup baik namun terdapat lonjakan pada iterasi akhir dan solusi globalnya masih mahal dibanding dengan populasi yang berjumlah lebih banyak. Semakin banyak individu yang dibangkitkan maka waktu komputasi yang dilakukan akan semakin lama.

Tabel 1

Solusi Terbaik Hasil Optimasi dari IEEE 30 bus

\begin{tabular}{|c|c|c|c|c|c|c|c|c|}
\hline Metode & OPF-LP & OPF-OKHA & $\begin{array}{l}\text { TSCOPF } \\
\text { GA [13] }\end{array}$ & $\begin{array}{c}\text { TSCOPF EPNN } \\
{[14]}\end{array}$ & $\begin{array}{c}\text { TSCOPF } \\
\text { ABC [15] }\end{array}$ & $\begin{array}{l}\text { TSCOPF } \\
\text { PSO }\end{array}$ & $\begin{array}{l}\text { TSCOPF } \\
\text { KHA }\end{array}$ & $\begin{array}{c}\text { TSCOPF } \\
\text { OKHA }\end{array}$ \\
\hline Pg1 (MW) & 41.54 & 43.226 & 41.88 & 48.95 & 42.65 & 43.031 & 44.155 & 43.221 \\
\hline $\operatorname{Pg} 2(\mathrm{MW})$ & 55.4 & 54.789 & 56.38 & 38.41 & 60.15 & 56.188 & 54.109 & 55.861 \\
\hline Pg13 (MW) & 16.2 & 19.379 & 22.94 & 23.34 & 17.96 & 18.356 & 17.196 & 17.484 \\
\hline Pg22 (MW) & 22.74 & 24.130 & 37.63 & 24.65 & 24.68 & 22.143 & 22.617 & 23.518 \\
\hline Pg23 (MW) & 16.27 & 17.342 & 16.7 & 17.61 & 15 & 16.601 & 17.033 & 17.166 \\
\hline Pg27 (MW) & 39.91 & 32.665 & 16.53 & 38.99 & 31.64 & 35.431 & 36.564 & 34.363 \\
\hline Vg1 (p.u.) & 0.982 & 1.038 & - & - & - & 1.011 & 1.028 & 1.016 \\
\hline Vg2 (p.u.) & 0.979 & 1.039 & - & - & - & 1.004 & 1.025 & 1.016 \\
\hline Vg13 (p.u.) & 1.064 & 1.033 & - & - & - & 1.025 & 1.035 & 1.050 \\
\hline Vg22 (p.u.) & 1.016 & 1.002 & - & - & - & 1.013 & 0.989 & 1.011 \\
\hline Vg23 (p.u.) & 1.026 & 1.011 & - & - & - & 1.016 & 0.998 & 1.018 \\
\hline Vg27 (p.u.) & 1.069 & 0.998 & - & - & - & 1.030 & 1.025 & 1.023 \\
\hline Biaya $(\$ / h r)$ & 576.89 & 574.43071 & 585.62 & 585.12 & 576.755 & $\mathbf{5 7 5 . 7 5 0}$ & 575.133 & $\mathbf{5 7 4 . 7 4 3}$ \\
\hline
\end{tabular}




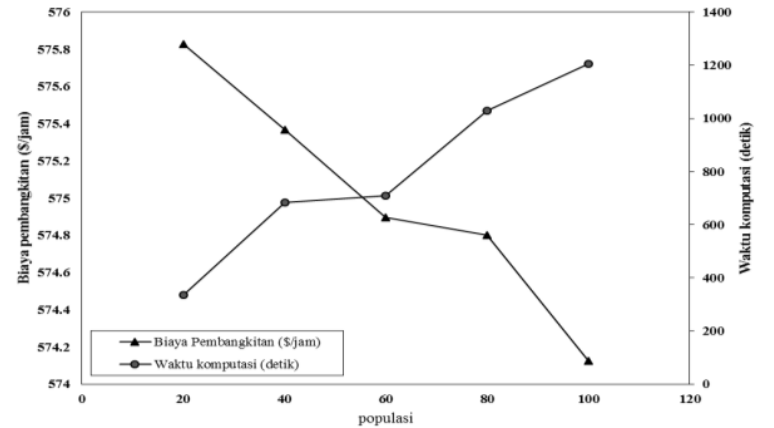

Gambar 3. Perbandingan Populasi, Biaya Pembangkitan dan Waktu Komputasi

Untuk populasi dengan jumlah individu 100 memiliki lama waktu komputasi 1204 detik. Sedangkan pada populasi dengan jumlah individu 60 memilki waktu komputasi 708 detik. Dari gambar 3 dapat dilihat jumlah individu untuk mendapatkan solusi global terbaik dengan waktu yang relatif cepat yaitu berkisar 40 - 60 individu.

Fault Clearing Time adalah waktu operasi circuit breaker untuk membuka, sehingga pada saluran yang mengalami gangguan dapat diisolasi. Besar FCT sendiri berpengaruh pada kebutuhan seting koordinasi. Semakin lama FCT berarti semakain fleksibel suatu CB dilakukan koordinasi proteksi. Pengaruh dari lama FCT terhadap biaya diperlihatkan pada gambar 4. FCT disimulasikan pada detik ke 0.18, 0.2, 0.3, 0.4, dan 0.5. Ketika FCT diset 0.5 detik maka solusi yang didapat dari analisa TSCOPF lebih mahal dibanding FCT yang dipasang 0.18 detik dengan beda $\$ 0.45$. Biaya pembangkitan (\$/jam) menunjukan kecenderungan lebih mahal ketika FCTnya naik. Hal ini disebabkan nilai ekonomis yang dikorbankan, sehingga generator yang memiliki fungsi biaya murah namun tidak stabil oleh karena saluran atau pembangkitnya mendekati batas, terpaksa besar pembangkitan dialihkan ke generator yang memiliki fungsi biaya yang mahal.Gambar respon sistem terhadap gangguan yang menyebabkan putusnya saluran dalam bentuk kurva sudut rotor dapat terlihat pada gambar 5. Gambar 5 menunjukan respon sistem setelah dilakukan TSCOPF. Hasil respon sudut rotor pada saat CB membuka pada detik ke 0.5 dengan sistem mula menunjukan bahwa generator tidak stabil. Ketidakstabilan ini dilihat dari sudut rotor generator 2 yang memisah dari sudut rotor generator yang lain dan tidak kembali menyatu.

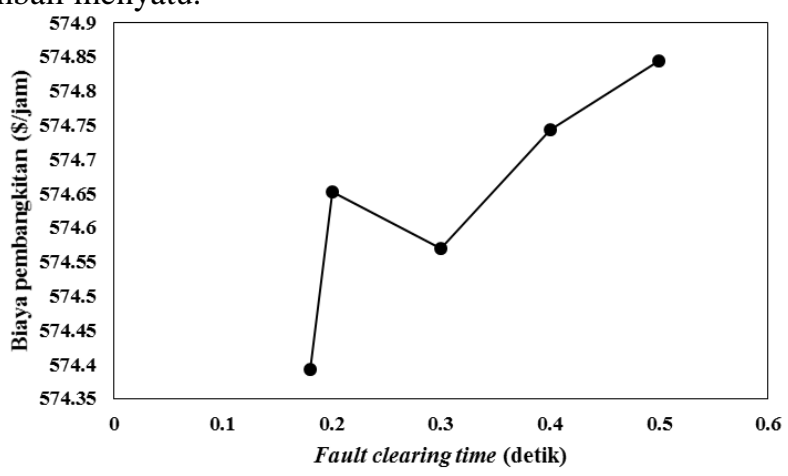

Gambar 4. Perbandingan FCT dengan Biaya Pembangkitan

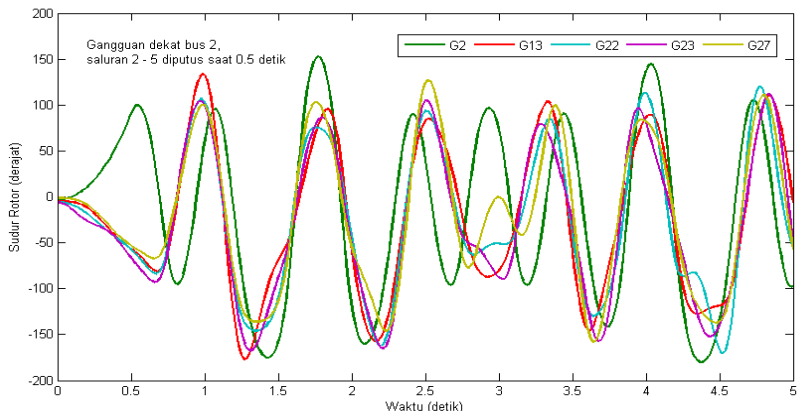

Gambar 5. Kurva Sudut Rotor Generator pada Sistem IEEE 30 untuk Kasus TSCOPF, dengan Fault Clearing Time 0.5 detik

Gambar 5 menunjukan sudut rotor yang tidak menyebar dan sudut rotor berayun pada sumbu yang sama setelah dilakukan analisa TSCOPF. Hal itu menunjukan kestabilan sistem setelah dilakukan kontingensi. Sudut rotor tidak meredam dan terus berayun tanpa mengalami peredaman ke suatu nilai, disebabkan permodelan generator berupa generator klasik dan tidak dimodelkan peredaman sistem.

\section{B. Sistem Jawa Bali $500 \mathrm{kV}$}

Sistem kedua yang digunakan untuk menguji analisa TSCOPF adalah sistem Jawa Bali 29 bus 10 generator. Data pembebanan pada sistem interkoneksi Jawa Bali diperoleh dari data lapangan melalui PT. PLN (Persero) P2B Jawa Bali yaitu menggunakan data pembebanan pada waktu beban puncak tanggal 14 Maret 2016 jam 19.00. Data fungsi biaya diambil dari fungsi biaya tiap generator yang telah dikomposit. Data permodelan generator mengambil dari referensi [5] dengan mengambil data konstanta inersia dan reaktansi transien. Kasus kontingensi dilakukan pada saluran antara bus Bekasi dan bus Cibinong berdasarkan referensi analisa perhitungan CCT pada sistem Jawa Bali 500kV [6]. Index kontingensi pada suatu saluran adalah nilai yang menunjukan saluran yang berbahaya atau paling aman terhadap keamanan operasi sistem tenaga listrik apabila terjadi gangguan pada saluran tersebut. Index ini digunakan hanya untuk mendukung analisa dan mengambil kesimpulan. Index kontingensi sistem Jawa Bali didapat dari referensi Power Load Performance Index [7]. Waktu FCT pada saluran antara bus Cibinong dan bus Bekasi adalah 0.122 detik, dengan waktu total simulasi 5 detik.

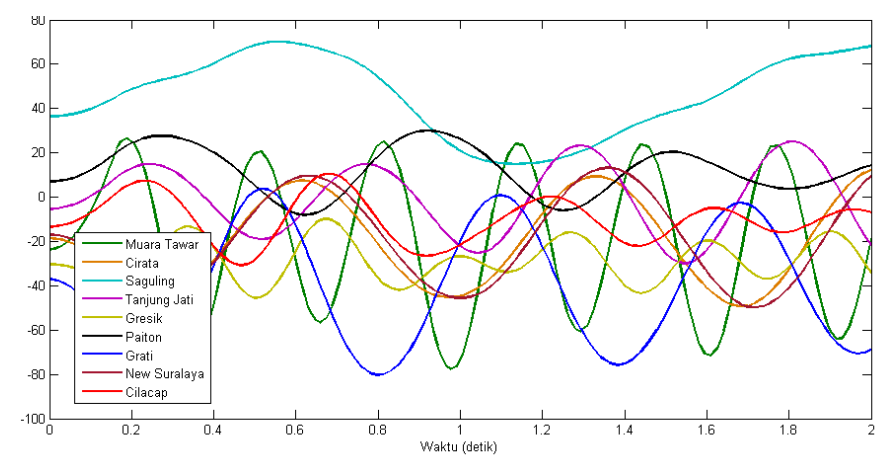

Gambar 6. Sudut rotor generator pada sistem Jamali 500kV untuk kasus TSCOPF, dengan fault clearing time 155 ms 
Tabel 2.

Solusi Terbaik Hasil Optimasi dari Jawa Bali 500kV

\begin{tabular}{cccccc}
\hline \hline & Inisial & \multirow{2}{*}{ Base OPF } & \multirow{2}{*}{ PSO TSCOPF } & \multirow{2}{*}{ KHA TSCOPF } & OKHA TSCOPF \\
\hline Pg1 (MW) & 2648.5220 & 1686.6116 & 2015.9922 & 2326.0873 & 1700.9196 \\
Pg8 (MW) & 2137.0000 & 982.0000 & 982.2760 & 983.4887 & 982.0000 \\
Pg10 (MW) & 290.6000 & 1008.0000 & 865.3078 & 1003.0511 & 1008.0000 \\
Pg11 (MW) & 4543.5500 & 700.0000 & 625.8350 & 699.9977 & 700.0000 \\
Pg15 (MW) & 458.3200 & 1415.5106 & 2053.8458 & 1728.0342 & 1960.0864 \\
Pg17 (MW) & 439.1500 & 211.0026 & 406.2972 & 526.9991 & 211.0000 \\
Pg22 (MW) & 503.0000 & 4714.0000 & 3534.7117 & 3456.2772 & 3801.5546 \\
Pg23 (MW) & 455.0000 & 185.0000 & 448.1698 & 185.0026 & 185.0000 \\
Pg26 (MW) & 691.9300 & 424.7785 & 732.1074 & 400.1396 & 780.0000 \\
Pg28 (MW) & 346.0000 & 1199.9886 & 843.5821 & 1190.0449 & 1200.0000 \\
Total Biaya pembangkitan & $\mathbf{R p} \mathbf{2 , 9 6 0 , 4 3 6 , 8 0 8 . 2 8}$ & $\mathbf{R p} \mathbf{2 , 8 8 5 , 9 8 5 , 7 1 0 . 3 2}$ & $\mathbf{R p} \mathbf{3 , 2 5 1 , 6 1 6 , 6 3 0 . 5 2}$ & $\mathbf{R p ~} \mathbf{3 , 0 3 3 , 3 0 9 , 6 3 8 . 3 7}$ & $\mathbf{R p} \mathbf{2 , 9 2 8 , 7 8 3 , 2 5 7 . 5 7}$ \\
\hline \hline
\end{tabular}

Pada tabel 2 menunjukan daya yang harus dibangkitkan pada setiap generator, dari hasil analisa OPF dan TSCOPF sistem Jawa Bali. Solusi yang dihasilkan baik tegangan bus generator maupun daya pembangkitan tidak ada yang melebihi kapasitas. Aliran daya yang mengalir pada saluran baik pada kasus mula maupun setelah TSCOPF tertera pada tabel 2 . Besar aliran daya yang mengalir pada saluran tidak ada yang melebihi kapasitas saluran. Untuk kasus OPF dasar maka besar biaya pembangkitan adalah Rp.2.885.985.710. Biaya pembangkitan dengan analisa TSCOPF paling murah menggunakan metode OKHA dengan nilai sebesar Rp.2.928.783.257. Urutan metode heuristik dengan biaya pembangkitan dari yang paling murah adalah OKHA, KHA, dan PSO. Biaya pembangkitan TSCOPF lebih mahal daripada OPF dengan selisih Rp. 42.797.547. Hal ini disebabkan oleh nilai ekonomis dari sistem operasi dikorbankan untuk meningkatkan performa kestabilan sistem.

Kurva sudut rotor setelah diberikan gangguan di saluran Bekasi - Cibinong dekat bus Cibinong dapat dilihat pada gambar 7. Gambar 7 adalah kurva sudut rotor pada sistem yang sudah dilakukan analisa OPF dengan batasan kestabilan transien. Hasil yang ditunjukan analisa OPF saja menunjukan ketidakstabilan sudut rotor yang ditandai dengan sudut rotor yang menyebar. Berbeda dengan solusi yang ditunjukan setelah dianalisa TSCOPF dimana kondisi sistem dikatakan stabil oleh karena kurva sudut rotor generator berayun pada sumbu yang sama.

Analisa TSCOPF adalah metode preventif yaitu mencegah terjadinya ketidakstabilan sudut rotor apabila terjadi gangguan. Namun dengan TSCOPF, nilai ekonomis dikorbankan sehingga biaya pembangkitan menjadi lebih mahal. Hal ini disebabkan pengalihan daya saluran dan pembebanan yang berbahaya menuju saluran atau pembangkit yang lebih stabil atau aman. Dilihat dari rangking index kontingensi Jawa Bali [7] tiga urutan teratas adalah saluran Tanjung Jati - Ungaran, Paiton - Grati, dan Paiton - Kediri.

Bisa dilihat pada aliran daya saluran Jawa Bali adanya penurunan aliran daya pada saluran yang terindeks kritis yaitu Ungaran - Tanjung Jati (14-15) sebesar 151.507 MVA, Paiton - Grati (22-23) sebesar 442.748 MVA, dan Paiton - Kediri sebesar 364.717 MVA. Hal ini berpengaruh juga pada penurunan daya pembangkitan generator tertentu yaitu pada pembangkit di Tanjung Jati, Paiton, dan Grati.

\section{KESIMPULAN}

Pada studi kasus ini, menunjukan bahwa metode OKHA adalah metode yang paling optimal untuk menyelesaikan masalah TSCOPF. Nilai CCT yang didapatkan dari analisa TSCOPF menjadi semakin besar, seperti pada Sistem Jawa Bali bertambah $65 \mathrm{~ms}$. TSCOPF adalah usaha preventif mencegah ketidakstabilan dengan mengatur jadwal pembangkitan. Ketika kebutuhan FCT meningkat dan menjadi kritis, maka diikuti dengan biaya pembangkitan yang naik. Pada pembebanan dengan menggunakan sistem IEEE 30 bus, pengujian TSCOPF dengan beberapa kali percobaan menghasilkan total biaya optimal senilai $\$ 574,743$ / jam atau lebih mahal \$0.312 dibanding pengujian menggunakan OPF. Hal yang sama terjadi pada sistem Jawa Bali 500kV dimana solusi TSCOPF lebih mahal Rp.42.797.547 dibanding solusi OPF. Hal ini terjadi karena nilai ekonomis dari sistem operasi dikorbankan untuk meningkatkan performa kestabilan sistem yang ditunjukan dengan respon sudut rotor yang stabil pada saat uji kontingensi.

\section{DAFTAR PUSTAKA}

[1] P.Kundur, Power System Stability and Control. New York: Mc Graw Hill, 1994.

[2] I. P. E. Society, "IEEE Guide for Synchronous Generator Modeling Practices and Applications in Power Systems Stability Analyses," Inst. Electr. Electron. Eng., 2003.

[3] I. P. E. Society, "IEEE Recommended Pratice for Industrial and Commercial Power Sytems Analysis," Inst. Electr. Electron. Eng., 1998.

[4] M. . Izzri, N., Wahab, A., Area based COI refererred rotor angle index for stability assessment and control of power systems, vol. 2012. Hindawi Publishing Corporation.

[5] R. Duanaputri, "Optimisasi Parameter PSS Berbasis Multi Mesin Menggunakan Modified Differential Evolution (MDE) Pada Sistem Jawa Bali $500 \mathrm{kV}$," ITS, 2017.

[6] O. A. Q. I. Budi Sulistiawati, A. Priyadi, "Critical Clearing Time Prediction within various loads for transient stability assessment by means of the Extreme Learning Machine method," Electr. Power Energy Syst., vol. 77, pp. 345-352, 2016.

[7] J. W. P. L. Multa Putranto, "Contingency Analysis on 500Kv Jawa Bali Transmission Line System Based on Power Load Performance Index," Inf. Technol. Electr. Eng., 2013. 